\title{
LAKES RESTORATION: ANALYSIS OF TERMINOLOGY INCORRECTLY USED IN THE SCIENTIFIC LITERATURE
}

\author{
Robert Mazur ${ }^{凶}$ \\ Department of Geoinformation, Photogrammetry and Remote Sensing of Environment, Faculty of Mining, Surveying and Environ- \\ mental Engineering, AGH University of Science and Technology, 30-059 Krakow
}

\begin{abstract}
Aim of the study

The analyses of improper use of the term "water restoration" and "restoration of the water reservoir", in order to show the errors that should be avoided in the proper description of the processes carried out in the field of water reservoir protection
\end{abstract}

\begin{abstract}
Material and methods
The study bases on the literature review for reports and research results in the field of the restoration of surface water and degraded water reservoirs. The author analyzed improper uses the term "water restoration" and suggested a correct form of the new professional term.
\end{abstract}

\section{Results and conclusions}

The results of the analysis of selected articles in the field of water reservoir reclamation clearly indicate that authors mistakenly used the phrase lake restoration in their papers. In the scientific and professional literature, the phrase lake remediation is overused despite the recommendations of world-renowned experts from the Committee on Restoration of Aquatic Ecosystems in USA, who presented in their reports the correct definition of the word water restoration.

Keywords: Lake restoration, water restoration, reclamation, water purification treatment, water pollution

\section{INTRODUCTION}

Degradation of water reservoirs remains a global problem, although its intensity in various regions of the world is changeable (Fu et al, 2003; Liu \& Diamond, 2005; Goel, 2006; Smol, 2009; Ongley, 2010; Ahuja, 2013). Discharge of improperly treated sewage is one of the main causes of contamination of inland watercourses and water reservoirs (Chmielowski and Ślizowski, 2008; Bugajski et al., 2016 a; Bugajski et al., 2016; Mazur et al., 2016; Młyński et al., 2017).

The Water Framework Directive (WFD) obliges EU member states to eliminate all causes of pollution under the threat of severe financial penalties (Kalli \& Butler, 2001; Mostert, 2003; Moss, 2008). Local administration bodies are increasingly looking for and implementing new measures for water reclamation in the area of their administration. The processes of water treatment conducted in order to restore them to the appropriate quality are most often based on the use of selected methods of purification treatment. In the subject literature globally, we find many reports on the purification treatment of water reservoirs (Bernhardt et al., 2005; Loomis, 2006; Palmer et al., 2007). The authors show a positive effect of the methods used, demonstrating the improvement of the tested parameters of polluted

凶e-mail:mazurrob@gmail.com 
water. Both the scientists and the experts in the field of water restoration technologies use the expression of "restoration of water reservoirs" or "water restoration". This term is widely used in many aspects of processes aimed at removing selected forms of water pollution. Also in the case of bottom sediment mining, the term "restoration" appears in the scientific literature. In the books devoted to the renewal of surface water quality, the following types of "restoration methods" are mentioned: chemical, biological and mechanical. In the vast majority of cases, the term is used incorrectly. At scientific conferences on the restoration of water reservoirs, research papers are presented, the results of which do not in fact present the effects of such restoration. Also the Water Law in Poland uses the word "restoration" (Polish: "rekultywacja"), the legal interpretation of which is ambiguous. The term "restoration of waters" has become widespread in the literature on the subject, and it has become very popular in both scientific and industry-related activities. The overuse, or abuse, of the term has led to information noise and to its misidentification with water purification processes. It is safe to say that we are dealing with negative transfer within the meaning of the term "water restoration" due to incorrect presentation of the process itself.

What are the reasons for the incorrect application of the aforementioned term? And why do scientists and experts reiterate that same error in scientific studies and expert reports?

The author has attempted to analyse the problem of improper use of the term "water restoration" and "restoration of the water reservoir", in order to show the errors that should be avoided in the proper description of the processes carried out in the field of water reservoir protection.

\section{METHODOLOGY}

The following stages can be distinguished in the work on the present paper:

1. Literature review for reports and research results in the field of the restoration of surface water and degraded water reservoirs.

2. Classification of papers due to the terminology used and the misuse of the concept of water restoration.

3. Suggestions for the correct use of terms and correct wording in the scientific and industry literature.

\section{RESULTS AND DISCUSSION}

Before we begin to analyse cases of misuse of the term "restoration of watercourses and water reservoirs", definition of this concept should be cited that would cover the full and comprehensive scope of the term. There are many original definitions in the scientific literature; unfortunately, a significant portion of these does not exhaust the broad area to which the term "water restoration" refers.

As recommended by world-class experts from the Committee on Restoration of Aquatic Ecosystems: Science, Technology, and Public Policy Water Science and Technology Board Commission on Geosciences, Environment, and Resources National Research Council, USA and US-EPA, the full definition of "water restoration" or "water reservoir restoration" includes:

Restoring all functions of the aquatic environment to the condition that prevailed in the given reservoir before its disturbance, which concerns physico-chemical parameters and biological water ecosystems (National Research Council, 1992).

Restoration should not be confused with purification, with creation of new forms of water habitats, or with improving water quality. Knowing the condition of the reservoir before the changes introduced by human activity, it may be necessary to carry out additional activities such as the reintroduction of species that had inhabited it previously, and withdrew from the habitat as a result of anthropogenic changes. The use of individual methods to improve selected parameters is usually insufficient for effecting the restoration of such a reservoir (National Research Council, 1992). The restoration process should take into account restoring the full trophic network, including the key species in the changed aquatic ecosystem. Partial actions typically tend to lead to such an ecosystem's continuing to function in a distorted form. The restoration process is aimed at "repairing" environmental damage with regard to restoring the appropriate degree of reproduction of renewable resources that were originally occurring therein (Spencer, 1985). It aims to restore the structure and function of these ecosystems in the aquatic environment (Naiman, 1988). Restoration is therefore holistic in character. Its goal is to achieve a close-to-natural state of the aquatic environment. We understand this state as a self-regulating system, close- 
ly integrated with the ecological landscape in which it is located (National Research Council, 1992).

Therefore, the restoration of a close-to-original state for the characteristic resources of renewable water ecosystems requires the application of an appropriate algorithm of operation.

An example of the algorithm of processes aimed at obtaining the proper restoration effect follows:

1. restoring the original hydrological and morphological conditions of the water reservoir,

2. application of chemical, mechanical and/or biological purification methods (for instance, bio-manipulation, or revitalization),

3. reintroduction of native species of aquatic organisms (plant and animal).

Before the restoration process can take place, it is extremely important to determine the initial state (original condition), to which this process should lead. In order to establish the algorithm of activities, a team of experts should be appointed, specialising in the management of water environment, who will correctly determine corrective actions, leading to the ultimate success. Developing a new quality of water environment in water reservoirs, different from their original state, is also not a part of the restoration process. If initially such a reservoir was silted and the waters were characterized by an elevated trophic level, or contained, for example, humic compounds, then the ultimate goal (end point) in its reclamation is to obtain an analogous state - rather than desilting the reservoir and reducing the level of trophic waters (Environmental Protection Agency, 1990).

In many cases, it is impossible to restore the original state of the water environment that occurred before the anthropogenic changes. This results from the irreversibility of morphometric changes in the landscape, reservoir morphology, microclimate, progressive industrialization, and so forth. Bearing in mind the above considerations, the process of water restoration should be focused on obtaining similar conditions in the changed area. Nevertheless, it is not possible to reduce restoration to individual measures or selective treatments aimed at improving water quality, unless its improvement will bring about restoration of the close-to-original state, in which case the reservoir can be considered restored (Lineman et al., 2014).

The most problematic issue is calling repair actions on artificial reservoirs (mainly dam reservoirs) a "res- toration", because here we are dealing with a new quality and creation of a new water ecosystem dependent on anthropogenic activity. In the USA, a number of campaigns of dam demolitions and restoration of natural conditions of ice-marginal valleys were undertaken. Scientists and experts are still arguing over whether the actions taken can be included in the meaning of the proper process of restoration of selected sections of ice-marginal valleys (American Rivers, 2014, O’Connor et al., 2015, Magilligan et al., 2016).

The author analysed the implemented treatments - as to whether or not they constitute restoration processes - looking at selected examples of fifteen lakes. These reservoirs belonged to various categories of lakes, differentiated due to their size, depth, as well as other hydro-morphological conditions (see: Table 1).

Table 1. Morphometric characteristics and mixing types of selected degraded lakes and water reservoirs subjected to restoration or improvement processes.

\begin{tabular}{llcccl}
\hline No. & $\begin{array}{l}\text { Name of the } \\
\text { reservoir }\end{array}$ & $\begin{array}{c}\text { Area } \\
{[\mathrm{ha}]}\end{array}$ & $\begin{array}{c}\text { Capacity } \\
{\left[\mathrm{hm}^{3}\right]}\end{array}$ & $\begin{array}{c}\text { Depth }[\mathrm{m}] \\
\text { mean }- \\
\text { maximum }\end{array}$ & $\begin{array}{c}\text { Lake type } \\
\text { based on } \\
\text { mixing }\end{array}$ \\
\hline 1 & Lake Ełckie & 382.4 & 7.779 & $15-55$ & dimictic \\
\hline 2 & Lake Długie & 26.8 & 1.414 & $5.3-17.3$ & bradymictic \\
\hline 3 & Lake Siekiera & 12 & 0.344 & $3-6$ & polymictic \\
\hline 4 & Cierpisz & 2.3 & 0.022 & $0.9-1.5$ & polymictic \\
\hline 5 & Kamionka & 7 & 0.105 & $1.5-3$ & polymictic \\
\hline 6 & Finjasjön & 1100 & - & $3-15$ & polymictic \\
\hline 7 & $\begin{array}{l}\text { Lake } \\
\text { Wolsztyńskie }\end{array}$ & 124 & 2.522 & $4.2-3.3$ & polymictic \\
\hline 8 & $\begin{array}{l}\text { Lake } \\
\text { Jelonek }\end{array}$ & 14.4 & 0.172 & $12-2.4$ & polymictic \\
\hline 9 & $\begin{array}{l}\text { Lake } \\
\text { Głęboczek }\end{array}$ & 17.4 & - & $3.3-5$ & polymictic \\
\hline 10 & Round Lake & 16.2 & - & $2.9-10.5$ & dimictic \\
\hline 11 & Lake Søga ${ }^{\circ}$ rd & 26 & - & 1.6 & polymictic \\
\hline 12 & Lake Tegel & 306 & - & $7.6-16$ & dimictic \\
\hline 13 & $\begin{array}{l}\text { Lake } \\
\text { Schlachtensee }\end{array}$ & 42 & - & $4.7-9$ & polymictic \\
\hline 14 & $\begin{array}{l}\text { Lake } \\
\text { Sønderby }\end{array}$ & 8 & - & $2.8-5.7$ & polymictic \\
\hline 15 & Lake Arresø & 4000 & - & $3.1-5.9$ & polymictic \\
\hline & & & & & \\
\hline
\end{tabular}


All water reservoirs studied were characterized by significant disturbances in the quality of water and in the functioning of inland ecosystems. In all, corrective measures were taken in order to improve selected qualitative and structural parameters (see: Table 2).

Table 2. Evaluation of the restoration process of the analysed reservoirs in the aspect of the activities carried out, and the final effect in accordance with the restoration criterion.

\begin{tabular}{|c|c|c|c|c|c|c|c|c|}
\hline No. & $\begin{array}{l}\text { The origin } \\
\text { and nature of } \\
\text { reservoir's } \\
\text { transfor- } \\
\text { mations }\end{array}$ & $\begin{array}{l}\text { Degree of } \\
\text { contami- } \\
\text { nation and } \\
\text { trophic } \\
\text { condition of } \\
\text { the water }\end{array}$ & $\begin{array}{l}\text { Undertaken } \\
\text { remedial } \\
\text { processes }\end{array}$ & $\begin{array}{c}\text { End result of } \\
\text { the improve- } \\
\text { ments }\end{array}$ & $\begin{array}{l}\text { Compliance } \\
\text { with the } \\
\text { restoration } \\
\text { process } \mathrm{Z}\end{array}$ & $\begin{array}{c}\text { Completeness } \\
\text { of the studied } \\
\text { parameters }\end{array}$ & $\begin{array}{l}\text { Suggested correct } \\
\text { title of the paper }\end{array}$ & References \\
\hline 1 & $\begin{array}{l}\text { Morpho- } \\
\text { metric } \\
\text { parameters } \\
\text { close to the } \\
\text { original ones, } \\
\text { with changes } \\
\text { of anthro- } \\
\text { pogenic } \\
\text { character. }\end{array}$ & $\begin{array}{l}\text { Hypertrophy } \\
\text { of water, and } \\
\text { a decrease } \\
\text { in water } \\
\text { transpa- } \\
\text { rency. }\end{array}$ & $\begin{array}{l}\text { Chemical } \\
\text { inactivation of } \\
\text { phosphorus, } \\
\text { oxygenation } \\
\text { without } \\
\text { de-esterifi- } \\
\text { cation. }\end{array}$ & $\begin{array}{l}\text { Improvement } \\
\text { of } \\
\text { transparency, } \\
\text { increase } \\
\text { of oxygen } \\
\text { concentration } \\
\text { in oxygen } \\
\text { profile, } \\
\text { reduction } \\
\text { of water } \\
\text { trophism. }\end{array}$ & $\begin{array}{l}\text { The reservoir } \\
\text { reclamation } \\
\text { effect has not } \\
\text { been obtained } \\
\text { despite the fact } \\
\text { that the applied } \\
\text { methods are } \\
\text { used in the } \\
\text { reclamation } \\
\text { process. }\end{array}$ & $\begin{array}{l}\text { The monitoring } \\
\text { study was based } \\
\text { on selective } \\
\text { studies that did } \\
\text { not provide the } \\
\text { opportunity } \\
\text { to assess the } \\
\text { reclamation } \\
\text { effect. }\end{array}$ & $\begin{array}{l}\text { Efekty redegradacji } \\
\text { Jeziora Ełckiego } \\
\text { metodą sztucznego } \\
\text { napowietrzania } \\
\text { i chemicznej } \\
\text { dezaktywacji } \\
\text { fosforu. (Re- } \\
\text { degradation effects } \\
\text { of the Ełckie Lake } \\
\text { by artificial aeration } \\
\text { and chemical } \\
\text { deactivation of } \\
\text { phosphorus) }\end{array}$ & $\begin{array}{l}\text { Bańkowska, } \\
\text { A. } 2008 .\end{array}$ \\
\hline
\end{tabular}

$\begin{array}{ll}\begin{array}{l}\text { It was created } \\ \text { as a result }\end{array} & \text { Mesotrophic } \\ \text { of natural } & \\ \text { processes - } & \\ \text { significant } & \\ \text { anthro- } & \\ \text { pogenic } & \\ \text { changes. } & \end{array}$

$\begin{array}{ll}\text { Chemical } & \text { Lowered } \\ \text { inactivation of } & \text { water } \\ \text { phosphorus. } & \text { trophism, } \\ & \text { increased } \\ & \text { plankton } \\ & \text { biodiversity, } \\ & \text { increased } \\ & \text { water } \\ & \text { transparency. }\end{array}$

Despite significant changes in terms of lake re-degradation - there is lack of information as to the transparency. storation of the quality of the aquatic environment close to its original state.
Studying the species composition of indicator organisms in order to assess water trophism; lack of detailed information on biogenic nutrient changes.

and

Ocena zastosowania Paturej, procesu inaktywacji 2008 . fosforu na trofię jeziora śródmiejskiego. (Evaluating the application of the phosphorus inactivation process, and its impact on the trophism of a midtown lake.)

\begin{tabular}{|c|c|c|c|}
\hline $\begin{array}{l}\text { Glacial lake } \\
\text { - with visible } \\
\text { anthropo- } \\
\text { genic changes. }\end{array}$ & $\begin{array}{l}\text { Hypertrophy } \\
\text { of waters; } \\
\text { and } \\
\text { hypertrophy } \\
\text { of the } \\
\text { Cerato- } \\
\text { phyllum }\end{array}$ & $\begin{array}{l}\text { Inactivation } \\
\text { of phosphorus } \\
\text { in sediments; } \\
\text { covering the } \\
\text { sediments } \\
\text { with a layer } \\
\text { of sand; } \\
\text { reconstruc- } \\
\text { tion of the } \\
\text { shoreline; } \\
\text { removing } \\
\text { macrophyte } \\
\text { biomass. }\end{array}$ & $\begin{array}{l}\text { Slight } \\
\text { decrease in } \\
\text { the ESMI } \\
\text { indicator, } \\
\text { reduction } \\
\text { of water } \\
\text { trophism, } \\
\text { reduction } \\
\text { of organic } \\
\text { suspensions. }\end{array}$ \\
\hline
\end{tabular}

Treatments
had a positive
effect on the
improvement
of water
quality and
thinning of
macrophyte
biomass;
reduction of
water trophism.
water trophism.

$\begin{array}{ll}\begin{array}{l}\text { Improvement of } \\ \text { water quality and } \\ \text { modifications of }\end{array} & \begin{array}{l}\text { Rewitalizacja } \\ \text { jeziora Siekiera. } \\ \text { Zmiany jakości }\end{array} \\ \text { moreservoir's } & \text { wody i osadów } \\ \text { brought about } & \text { 2014-2016 r. } \\ \text { a new, better } & \text { (Revitalization } \\ \text { quality for } & \text { of lake Siekiera. } \\ \text { the reservoir } & \text { Changes in the } \\ \text { - however, } & \text { quality of water and } \\ \text { this does not } & \text { bottom sediments } \\ \text { correspond to } & \text { in the period 2014- } \\ \text { the principle of } & \text { 2016.) } \\ \text { restoration. } & \end{array}$

Bryl et al., 2017. 


\begin{tabular}{|c|c|c|c|c|c|c|c|c|}
\hline 4 & $\begin{array}{l}\text { Artificial - } \\
\text { dam-type } \\
\text { reservoir. }\end{array}$ & $\begin{array}{l}\text { Hypertrophy } \\
\text { of water, and } \\
\text { a decrease } \\
\text { in water } \\
\text { transparency }\end{array}$ & $\begin{array}{l}\text { Mechanical } \\
\text { desilting, } \\
\text { removal } \\
\text { of bottom } \\
\text { sediments. }\end{array}$ & $\begin{array}{l}\text { No visible } \\
\text { improvement } \\
\text { effects. }\end{array}$ & $\begin{array}{l}\text { No information } \\
\text { about obtaining } \\
\text { the restoration } \\
\text { effect (it is } \\
\text { not possible to } \\
\text { restore/reclaim } \\
\text { an artificial } \\
\text { reservoir). }\end{array}$ & $\begin{array}{l}\text { Selective } \\
\text { monitoring } \\
\text { testing of } \\
\text { physico-chemical } \\
\text { parameters of } \\
\text { waters, and } \\
\text { biomonitoring } \\
\text { based on the } \\
\text { use of indicator } \\
\text { organisms for the } \\
\text { eutrophication } \\
\text { process. }\end{array}$ & $\begin{array}{l}\text { Analiza } \\
\text { skuteczności } \\
\text { odmulania } \\
\text { zbiorników } \\
\text { wodnych Cierpisz } \\
\text { i Kamionka jako } \\
\text { efektywnej metody } \\
\text { rewitalizacji } \\
\text { ekosystemów } \\
\text { eutroficznych. } \\
\text { (Analysis } \\
\text { of desilting } \\
\text { effectiveness } \\
\text { in Cierpisz and } \\
\text { Kamionka water } \\
\text { reservoirs as an } \\
\text { effective method } \\
\text { of revitalising } \\
\text { eutrophic } \\
\text { ecosystems). }\end{array}$ & $\begin{array}{l}\text { Bartoszek } \\
\text { et al., } 2017 .\end{array}$ \\
\hline 5 & $\begin{array}{l}\text { Artificial - } \\
\text { dam-type } \\
\text { reservoir. }\end{array}$ & $\begin{array}{l}\text { Mesotrophic } \\
\text { waters }\end{array}$ & $\begin{array}{l}\text { Mechanical } \\
\text { desilting, } \\
\text { removal } \\
\text { of bottom } \\
\text { sediments. }\end{array}$ & $\begin{array}{l}\text { No visible } \\
\text { improvement } \\
\text { effects. }\end{array}$ & $\begin{array}{l}\text { No information } \\
\text { about obtaining } \\
\text { the reclamation } \\
\text { effect (it is } \\
\text { not possible } \\
\text { to reclaim } \\
\text { the artificial } \\
\text { reservoir). }\end{array}$ & $\begin{array}{l}\text { Selective } \\
\text { monitoring of } \\
\text { physico-chemical } \\
\text { parameters } \\
\text { of waters and } \\
\text { biomonitoring } \\
\text { based on the } \\
\text { use of indicator } \\
\text { organisms for the } \\
\text { eutrophication } \\
\text { process. }\end{array}$ & $\begin{array}{l}\text { Analiza } \\
\text { skuteczności } \\
\text { odmulania } \\
\text { zbiorników } \\
\text { wodnych Cierpisz } \\
\text { i Kamionka jako } \\
\text { efektywnej metody } \\
\text { rewitalizacji } \\
\text { ekosystemów } \\
\text { eutroficznych. } \\
\text { (Analysis } \\
\text { of desilting } \\
\text { effectiveness } \\
\text { in Cierpisz and } \\
\text { Kamionka water } \\
\text { reservoirs as an } \\
\text { effective method } \\
\text { of revitalising } \\
\text { eutrophic } \\
\text { ecosystems). }\end{array}$ & $\begin{array}{l}\text { Bartoszek } \\
\text { et al., } 2017 .\end{array}$ \\
\hline 6 & $\begin{array}{l}\text { Morpho- } \\
\text { metric } \\
\text { parameters } \\
\text { close to the } \\
\text { original ones, } \\
\text { with anthropo- } \\
\text { genic changes. }\end{array}$ & $\begin{array}{l}\text { Hypertrophy } \\
\text { of water, and } \\
\text { a decrease } \\
\text { in water } \\
\text { transparency, } \\
\text { significant } \\
\text { amount } \\
\text { of bottom } \\
\text { sediments, } \\
\text { disturbances } \\
\text { in the food } \\
\text { chain. }\end{array}$ & $\begin{array}{l}\text { 1st stage - } \\
\text { dredging, } \\
\text { 2nd stage } \\
\text {-biomani- } \\
\text { pulation, } \\
\text { 3rd stage - } \\
\text { construction } \\
\text { of a buffer } \\
\text { zone: artificial } \\
\text { marshland. }\end{array}$ & $\begin{array}{l}\text { Achieved } \\
\text { improvement } \\
\text { of visibility, } \\
\text { reduction } \\
\text { of biogenic } \\
\text { nutrients- } \\
\text { (mainly } \\
\text { phosphorus); } \\
\text { however, } \\
\text { disturbances } \\
\text { remain in } \\
\text { the structure } \\
\text { of trophic } \\
\text { networks. }\end{array}$ & $\begin{array}{l}\text { Partial } \\
\text { improvement } \\
\text { in the physical } \\
\text { and chemical } \\
\text { parameters of } \\
\text { waters. Slight } \\
\text { improvement } \\
\text { in the } \\
\text { biological } \\
\text { parameters } \\
\text { of the aquatic } \\
\text { environment. } \\
\text { This does not } \\
\text { represent a } \\
\text { complete effect } \\
\text { of reclamation. }\end{array}$ & $\begin{array}{l}\text { Monitoring tests: } \\
\text { physico-chemical } \\
\text { and biological. }\end{array}$ & $\begin{array}{l}\text { Multiple } \\
\text { techniques for lake } \\
\text { reclamation. }\end{array}$ & $\begin{array}{l}\text { Annadotter } \\
\text { et al., } 1999 .\end{array}$ \\
\hline
\end{tabular}




\begin{tabular}{|c|c|c|c|c|c|c|c|c|}
\hline 7 & $\begin{array}{l}\text { Morpho- } \\
\text { metric } \\
\text { parameters } \\
\text { close to the } \\
\text { original ones, } \\
\text { with anthropo- } \\
\text { genic changes. }\end{array}$ & $\begin{array}{l}\text { Hypertrophy } \\
\text { of water, and } \\
\text { a decrease } \\
\text { in water } \\
\text { transparency, } \\
\text { significant } \\
\text { amount } \\
\text { of bottom } \\
\text { sediments, } \\
\text { disturbances } \\
\text { in the food } \\
\text { chain. }\end{array}$ & $\begin{array}{l}\text { Phosphorus } \\
\text { inactivation in } \\
\text { the sediments. }\end{array}$ & $\begin{array}{l}\text { Lowering } \\
\text { phosphorus } \\
\text { content } \\
\text { and water } \\
\text { trophism, } \\
\text { increasing } \\
\text { water } \\
\text { transparency, } \\
\text { reducing } \\
\text { chlorophyll } \\
\text { concentration. }\end{array}$ & $\begin{array}{l}\text { Partial } \\
\text { improvement } \\
\text { in water quality } \\
\text { parameters. } \\
\text { The effect } \\
\text { of full } \\
\text { reclamation } \\
\text { has not been } \\
\text { demonstrated. }\end{array}$ & $\begin{array}{l}\text { Selected } \\
\text { phosphorus } \\
\text { content } \\
\text { monitoring } \\
\text { tests, selective } \\
\text { biomonitoring } \\
\text { tests. }\end{array}$ & $\begin{array}{l}\text { The title is correct } \\
\text { - in the content we } \\
\text { find information } \\
\text { about the effects of } \\
\text { lake reclamation. }\end{array}$ & $\begin{array}{l}\text { Bryl \& } \\
\text { Wiśniewski, } \\
2015 .\end{array}$ \\
\hline 8 & $\begin{array}{l}\text { Morpho- } \\
\text { metric } \\
\text { parameters } \\
\text { close to the } \\
\text { original ones, } \\
\text { with anthropo- } \\
\text { genic changes. }\end{array}$ & $\begin{array}{l}\text { Hypertrophy } \\
\text { of water } \\
\text { as well as } \\
\text { significant } \\
\text { amount } \\
\text { of bottom } \\
\text { sediments. }\end{array}$ & $\begin{array}{l}\text { Phosphorus } \\
\text { inactivation in } \\
\text { sediments. }\end{array}$ & $\begin{array}{l}\text { Lowering } \\
\text { phosphorus } \\
\text { content } \\
\text { and water } \\
\text { trophism, } \\
\text { increasing } \\
\text { water } \\
\text { transparency, } \\
\text { reducing } \\
\text { chlorophyll } \\
\text { concentration. }\end{array}$ & $\begin{array}{l}\text { Significant } \\
\text { improvement } \\
\text { in water quality } \\
\text { parameters. }\end{array}$ & $\begin{array}{l}\text { Selected } \\
\text { phosphorus } \\
\text { content and other } \\
\text { physic-chemical } \\
\text { parameters } \\
\text { monitoring } \\
\text { tests, extended } \\
\text { biomonitoring } \\
\text { tests. }\end{array}$ & $\begin{array}{l}\text { The condition and } \\
\text { potential methods } \\
\text { of reclamation of } \\
\text { shallow, urban Lake } \\
\text { Jelonek. }\end{array}$ & $\begin{array}{l}\text { Wiśniewski, } \\
2007 .\end{array}$ \\
\hline 9 & $\begin{array}{l}\text { Morpho- } \\
\text { metric } \\
\text { parameters } \\
\text { close to the } \\
\text { original ones, } \\
\text { with anthropo- } \\
\text { genic changes. }\end{array}$ & $\begin{array}{l}\text { Hypertrophy } \\
\text { of water, and } \\
\text { a decrease } \\
\text { in water } \\
\text { transparency }\end{array}$ & $\begin{array}{l}\text { Missing } \\
\text { information }\end{array}$ & $\begin{array}{l}\text { Seasonal } \\
\text { variability of } \\
\text { microbio- } \\
\text { logical } \\
\text { parameters in } \\
\text { lake water. }\end{array}$ & $\begin{array}{l}\text { There is no } \\
\text { information } \\
\text { that would } \\
\text { indicate the } \\
\text { process of } \\
\text { reclamation. }\end{array}$ & $\begin{array}{l}\text { Very selective } \\
\text { microbiological } \\
\text { tests - no other } \\
\text { information. }\end{array}$ & $\begin{array}{l}\text { Jakość wód } \\
\text { powierzchniowych } \\
\text { na przykładzie } \\
\text { Jeziora Głęboczek. } \\
\text { (Surface water } \\
\text { quality as illustrated } \\
\text { with the example of } \\
\text { lake Głęboczek). }\end{array}$ & $\begin{array}{l}\text { Traczy- } \\
\text { kowski, et al. } \\
2009 .\end{array}$ \\
\hline 10 & $\begin{array}{l}\text { Morpho- } \\
\text { metric } \\
\text { parameters } \\
\text { close to the } \\
\text { original ones, } \\
\text { with anthropo- } \\
\text { genic changes. }\end{array}$ & $\begin{array}{l}\text { Hypertrophy } \\
\text { of water, and } \\
\text { a decrease } \\
\text { in water } \\
\text { transparency }\end{array}$ & $\begin{array}{l}\text { Biomani- } \\
\text { pulation. }\end{array}$ & $\begin{array}{l}\text { Significant } \\
\text { improvement } \\
\text { of physico- } \\
\text { chemical } \\
\text { parameters, } \\
\text { of water } \\
\text { transparency; } \\
\text { decreased } \\
\text { trophism and } \\
\text { stabilization } \\
\text { of relations in } \\
\text { food chains } \\
\text { of the lake } \\
\text { ecosystem. }\end{array}$ & $\begin{array}{l}\text { Significant } \\
\text { improvement } \\
\text { of many } \\
\text { parameters } \\
\text { of the aquatic } \\
\text { environment; } \\
\text { however, the } \\
\text { full effect } \\
\text { characteristic } \\
\text { of the } \\
\text { reclamation of } \\
\text { the reservoir } \\
\text { has not been } \\
\text { achieved. }\end{array}$ & $\begin{array}{l}\text { Monitoring } \\
\text { of selected } \\
\text { physico-chemical } \\
\text { parameters } \\
\text { and advanced } \\
\text { research into } \\
\text { the biological } \\
\text { parameters. }\end{array}$ & $\begin{array}{l}\text { Lake reclamation } \\
\text { by biomanipulation } \\
\text { Round Lake, } \\
\text { Minnesota, the first } \\
\text { two years. }\end{array}$ & $\begin{array}{l}\text { Wright, } \\
1984 .\end{array}$ \\
\hline 11 & $\begin{array}{l}\text { Morphometric } \\
\text { parameters } \\
\text { close to the } \\
\text { original } \\
\text { ones, with } \\
\text { anthropogenic } \\
\text { changes. }\end{array}$ & $\begin{array}{l}\text { Hypertrophy } \\
\text { of water, and } \\
\text { a decrease } \\
\text { in water } \\
\text { transparency }\end{array}$ & $\begin{array}{l}\text { Biomani- } \\
\text { pulation. }\end{array}$ & $\begin{array}{l}\text { Improvement } \\
\text { of } \\
\text { transparency, } \\
\text { reduction } \\
\text { of water } \\
\text { trophism, } \\
\text { disturbances } \\
\text { in the food } \\
\text { chain. }\end{array}$ & $\begin{array}{l}\text { Improvement } \\
\text { of selected } \\
\text { physico- } \\
\text { chemical } \\
\text { parameters } \\
\text { of water has } \\
\text { been shown; } \\
\text { however, the } \\
\text { effect of water } \\
\text { reservoir } \\
\text { reclamation } \\
\text { was not } \\
\text { obtained. }\end{array}$ & $\begin{array}{l}\text { Monitoring } \\
\text { of selected } \\
\text { physico-chemical } \\
\text { parameters and } \\
\text { biomonitoring of } \\
\text { the lake macro- } \\
\text { fauna. }\end{array}$ & $\begin{array}{l}\text { Biomanipulating } \\
\text { streams: a } \\
\text { supplementary } \\
\text { tool in lake } \\
\text { rehabilitation }\end{array}$ & $\begin{array}{l}\text { Skov et al., } \\
2019 .\end{array}$ \\
\hline
\end{tabular}




\begin{tabular}{|c|c|c|c|c|c|c|c|c|}
\hline 12 & $\begin{array}{l}\text { Morphometric } \\
\text { parameters } \\
\text { close to the } \\
\text { original } \\
\text { ones, with } \\
\text { anthropogenic } \\
\text { changes. }\end{array}$ & $\begin{array}{l}\text { Hypertrophy } \\
\text { of water, and } \\
\text { a decrease } \\
\text { in water } \\
\text { transparency }\end{array}$ & $\begin{array}{l}\text { Stage } 1- \\
\text { construction } \\
\text { of a treatment } \\
\text { plant to reduce } \\
\text { phosphorus } \\
\text { content at } \\
\text { the lake's } \\
\text { inlet. Stage } \\
2 \text { - aeration } \\
\text { and chemical } \\
\text { inactivation of } \\
\text { phosphorus. }\end{array}$ & $\begin{array}{l}\text { Significant } \\
\text { reduction of } \\
\text { phosphorus } \\
\text { load in the } \\
\text { water and in } \\
\text { sediments. }\end{array}$ & $\begin{array}{l}\text { The reduction } \\
\text { of phosphorus } \\
\text { load was } \\
\text { demonstrated, } \\
\text { without } \\
\text { describing } \\
\text { other } \\
\text { qualitative } \\
\text { parameters } \\
\text { of the lake's } \\
\text { waters; the } \\
\text { obtained effect } \\
\text { does not meet } \\
\text { the criterion of } \\
\text { the reclamation } \\
\text { process. }\end{array}$ & $\begin{array}{l}\text { Monitoring } \\
\text { of chemical } \\
\text { parameters - } \\
\text { phosphorus } \\
\text { concentration. }\end{array}$ & $\begin{array}{l}\text { Assessment of } \\
\text { internal and } \\
\text { external lake } \\
\text { treatment measures } \\
\text { for two Berlin } \\
\text { lakes. }\end{array}$ & $\begin{array}{l}\text { Schauser } \\
\text { \& Chorus, } \\
2007 .\end{array}$ \\
\hline 15 & $\begin{array}{l}\text { Morphometric } \\
\text { parameters } \\
\text { close to the } \\
\text { original } \\
\text { ones, with } \\
\text { anthropogenic } \\
\text { changes. }\end{array}$ & $\begin{array}{l}\text { Hypertrophy } \\
\text { of water, and } \\
\text { a decrease } \\
\text { in water } \\
\text { transparency }\end{array}$ & $\begin{array}{l}\text { Biomani- } \\
\text { pulation (up to } \\
\text { down). }\end{array}$ & $\begin{array}{l}\text { Significant } \\
\text { reduction of } \\
\text { phosphorus } \\
\text { load in } \\
\text { the water, } \\
\text { improved } \\
\text { water } \\
\text { transparency. }\end{array}$ & $\begin{array}{l}\text { The reduction } \\
\text { of phosphorus } \\
\text { load and } \\
\text { improved } \\
\text { water } \\
\text { transparency } \\
\text { were } \\
\text { demonstrated, } \\
\text { as well as } \\
\text { decreased } \\
\text { degree of } \\
\text { eutrophication; } \\
\text { the obtained } \\
\text { effect does } \\
\text { not meet the } \\
\text { criterion of the } \\
\text { reclamation } \\
\text { process. }\end{array}$ & $\begin{array}{l}\text { Monitoring of } \\
\text { physico-chemical } \\
\text { parameters as } \\
\text { well as selected } \\
\text { biological } \\
\text { parameters. }\end{array}$ & $\begin{array}{l}\text { Reclamation of } \\
\text { shallow lakes by } \\
\text { nutrient control and } \\
\text { biomanipulation } \\
\text { - the successful } \\
\text { strategy varies } \\
\text { with lake size and } \\
\text { climate. }\end{array}$ & $\begin{array}{l}\text { Jeppesen } \\
\text { et al., } 2007 .\end{array}$ \\
\hline
\end{tabular}


Original titles of the papers containing the results of monitoring works on the improvement of degraded lakes and reservoirs (from Table 2) are as follows:

1. Efekty rekultywacji Jeziora Ełckiego metodą sztucznego napowietrzania i chemicznej dezaktywacji fosforu. (Lake Ełckie restoration effects with application of artificial aeration and chemical phosphorus deactivation methods)

2. Wpływ Rekultywacji na Trofię Jeziora Śródmiejskiego (The impact of Lake Śródmiejskie restoration processes on the trophy of water)

3. Rekultywacja Jeziora Siekiera. Zmiany jakości wody i osadów dennych w okresie 2014-2016 r. (Lake Siekiera restoration. The changes in water and bottom sediments quality in period of 2014 2016)

4. Analiza skuteczności odmulania zbiorników wodnych Cierpisz i Kamionka jako efektywnej metody rekultywacji ekosystemów eutroficznych. (Analysis of the effectiveness of desolation of water reservoirs Cierpisz and Kamionka as an effective method of restoration of eutrophic ecosystems).

5. Analiza skuteczności odmulania zbiorników wodnych Cierpisz i Kamionka jako efektywnej metody rekultywacji ekosystemów eutroficznych. (Analysis of the effectiveness of desolation of water reservoirs Cierpisz and Kamionka as an effective method of restoration of eutrophic ecosystems).

6. Multiple techniques for lake restoration.

7. Efekty inaktywacji fosforu $\mathrm{w}$ osadach dennych jeziora Wolsztyńskiego.(The effects of phosphorus inactivation in bottom sediments of Lake Wolsztyńskie)

8. The condition and potential methods of restoration of shallow, urban Lake Jelonek.

9. Jakość wód powierzchniowych po rekultywacji na przykładzie Jeziora Głęboczek. (The quality of surface water after restoration on the example of Lake Głęboczek)

10. Lake restoration by biomanipulation: Round Lake, Minnesota, the first two years.

11. Biomanipulating streams: a supplementary tool in lake restoration.

12. Assessment of internal and external lake restoration measures for two Berlin lakes.

13. Assessment of internal and external lake restoration measures for two Berlin lakes.
14. Lake restoration by dosing aluminum relative to mobile phosphorus in the sediment.

15. Restoration of shallow lakes by nutrient control and biomanipulation - the successful strategy varies with lake size and climate.

In all of the analysed papers, the authors failed to show the complete effect of reclamation, in line with the definition presented by a team of experts $(\mathrm{Na}-$ tional Research Council, 1992). All articles provide valuable information on the effectiveness of selected methods - which are applicable also in water restoration - having said that, these operations were directed at improving only specific quality parameters and structural parameters of the water bodies. All the water reservoirs described in the examined papers have specific functions - either utility, recreational, retention, drinking water intake, or others (Wright, 1984; Annadotter et al., 1999; Wiśniewski, 2007; Schauser and Chorus, 2007; Paturej, 2007; Bryl et al., 2017). Some of these are dammed reservoirs, created as a result of purposeful human activity, also for utility purposes (Bartoszek et al., 2017). None of the scientific reports provided information on the original state of the reservoir before the occurrence of distortions resulting from anthropogenic stress. The activities carried out were aimed at improving the aesthetic parameters of these reservoirs and restoring adequate water quality (Bańkowska, 2008, Traczykowski et al., 2009, Bryl and Wiśniewski, 2015, Skov et al., 2019). In other papers, including review papers, erroneous phrases suggesting a restoration process are often cited when in fact it did not take place (Funk and Gibbons, 1979; Zhao et al., 2003; Jeppesen et al., 2005; Berleć et al. 2009).

Therefore, one should ask a key question whether improvement actions are possible, which will result in the effect of full restoration of the water reservoir?

In many cases, even at the stage of planning improvement processes in degraded lakes and other water reservoirs, the restoration process should be clearly excluded. This category includes all kinds of artificial reservoirs, and reservoirs adapted to the needs of the local community or tourism in regions with specific, unique natural or cultural values. Improving the proper quality of water and the proper functioning of aquatic ecosystems does not yet lead restoring the original condition. Dam reservoirs constitute a new 
quality, and the ecosystems formed therein are secondary creations - therefore any restoration would imply necessity to restore the ice-marginal valley to its primary functions and to eliminate the dam, which is impossible. The dam itself stops the continuity of the bed load transport process, and it changes the hydrological and microclimatic conditions of the region in which the reservoir of this type is located (Mazur et al., 2016, Hämmerling et al., 2019). Also, the remaining reservoirs with specific functions made available, in many cases cannot be restored to the original state, due to local, cultural, industrial, or other considerations. At most, it is possible to implement effective purification or purge processes in order to obtain good quality water, or to improve conditions for sailing and other recreational activities.

The word "restoration" has become a fashionable term, whereas projects in the field of water reservoir renewal have become very profitable business for companies who specialise in this area (Bernhardt et al., 2005). These operations can be classified as revitalization, which according to the definition "is a process of reverting the critical condition of degraded areas, conducted in a comprehensive manner, through integrated activities for the benefit of the local community, space, and economy, territorially focused, carried out by stakeholders of revitalization based on the municipal revitalization program." (Journal of Laws, 2015, item 1777). According to this provision, most of the activities carried out in the field of water quality improvement can also be considered parts of the revitalization process. In the Environmental Protection Law you can also find the term "remediation", which according to that same Law "means submitting the soil, ground and groundwater to activities aimed at removing or reducing the amount of substances causing risk, controlling these substances and limiting their spread, so that the contaminated area ceases to pose threat to human health or the natural environment, taking into account the current and, if possible, future use of the area; remediation may involve self-purification if it brings the greatest environmental benefits". (Journal of Laws 2018, item 799). Some of the water treatment activities in reservoirs can also be described as a process of "remediation" or "bioremediation", replacing the inappropriately used term of "restoration" (Polish: "reklamacja").
In the industry-specific jargon, the term "restoration" is commonly used and understood as a synonym for all processes such as purification, water renewal, desilting, creation of new lake utility structures, and so forth.

In the literature of the subject, we also find examples of reservoirs that had been subjected to restoration processes, in which the correct effect of restoring a degraded lake was obtained (Olem and Flock, 1990, National Research Council, 1992). The most common cases of this are found in protected areas, where the reservoir cannot be used for recreational or industrial purposes. In these reservoirs, comprehensive processes are conducted aimed at restoring the original water quality, at restoring the disturbed primary structures of the food chain, and reintroducing species that existed there before these reservoirs' degradation.

In the Water Law in Poland, a new provision was introduced, stating that selected activities within water reservoirs require water permits (Journal of Laws of 2017, item 1566, Filipek et al., 2018). Such activities include the restoration of surface waters or groundwater. Companies and other legal entities wanting to treat the given reservoir must, therefore, obtain the necessary permits. Many companies, in order to shorten the time of waiting for appropriate permits and be able to carry out repair activities in reservoirs, opt for naming their services in another way, for instance, as re-degradation, water renewal or water treatment. Under Polish law, these types of operations do not require additional permits, therefore, in legal interpretation they are not identical to water restoration. Paradoxically, the aforementioned legal provision has contributed to reducing the abuse of the term "restoration" in various remedial actions in water reservoirs, although this was not the main intention behind it.

\section{CONCLUSIONS}

1. According to the definition of "water restoration" adopted by world-class experts, this term is reserved for processes aiming at the complete restoration of the water reservoir to its original state, which had been formed during its initial succession.

2. In many scientific articles and industry reports, this term is equated with other, selective corrective actions, designed to improve only some of the 
water parameters or the structure of the aquatic environment.

3. The term "water restoration" is undoubtedly misused, abused, or incorrectly applied, to corrective actions carried out in a narrow scope.

4. Water Law in Poland introduced changes that have had a positive impact on reducing the abuse of the term in question.

5. The misuse of words commonplace in industrial jargon causes information noise, and has a negative transfer effect in the wrong understanding of this wording by people who acquire specialized vocabulary (including secondary school and university students).

6. Researchers and experts must pay special attention to the proper naming of water rehabilitation activities

\section{REFERENCES}

Ahuja, S. (Ed.). (2013). Monitoring water quality: Pollution assessment, analysis, and remediation. Newnes.

American Rivers. (2014). Mapping Dam Removal Success. http://www.americanrivers.org/blog/mapping-dam-removal-success/.

Annadotter, H., Cronberg, G., Aagren, R., Lundstedt, B., Nilsson, P. Á., \& Ströbeck, S. (1999). Multiple techniques for lake restoration. In The Ecological Bases for Lake and Reservoir Management. Springer, Dordrecht, $77-85$.

Bańkowska, A. (2008). Efekty rekultywacji Jeziora Ełckiego metodą sztucznego napowietrzania i chemicznej dezaktywacji fosforu. Zeszyty Problemowe Postępów Nauk Rolniczych, 532, 21-28.

Bartoszek, L., Gruca-Rokosz, R., Koszelnik, P. (2017). Analiza skuteczności odmulania zbiorników wodnych Cierpisz i Kamionka jako efektywnej metody rekultywacji ekosystemów eutroficznych. Rocznik Ochrona Środowiska, 19, 600-617.

Berleć, K., Jurek, A., Michalska, M., Traczykowski, A. (2009). Mikroflora rekultywowanych zbiorników wodnych na przykładzie Jeziora Rudnickiego Wielkiego. Rocznik Ochrona Środowiska, 11, 1029-1040.

Bernhardt, E. S., Palmer, M. A., Allan, J. D., Alexander, G., Barnas, K., Brooks, S., Galat, D. (2005). Synthesizing US river restoration efforts. Science. 2005 Apr 29;308(5722):636-7.

Bryl, Ł., Wiśniewski, R. (2015). Efekty inaktywacji fosforu w osadach dennych jeziora Wolsztyńskiego.
Bryl, Ł., Wiśniewski, R., Sobczyński, T. Rekultywacja jeziora Siekiera. Zmiany jakości wody i osadów dennych w okresie 2014-2016 r.

Filipek, K., Kucharski, M., Michalski, P. (2018). Nowe prawo wodne. Najważniejsze zmiany dla gmin i przedsiębiorstw wodociągowo-kanalizacyjnych.

Fu, J., Mai, B., Sheng, G., Zhang, G., Wang, X., Peng, P. A., Wang, Z. (2003). Persistent organic pollutants in environment of the Pearl River Delta, China: an overview. Chemosphere, 52(9), 1411-1422.

Funk, W. H., Gibbons, H. L. (1979). Lake restoration by nutrient inactivation. Lake Restoration Report.

Goel, P. K. (2006). Water pollution: causes, effects and control. New Age International.

Hämmerling, M., Walczak, N., Nowak, A., Mazur, R., \& Chmist, J. (2019). Modelling Velocity Distributions and River Bed Changes Using Computer Code SSIIM below Sills Stabilizing the Riverbed. Polish Journal of Environmental Studies, 28(3).

Jeppesen, E., Meerhoff, M., Jacobsen, B. A., Hansen, R. S., Søndergaard, M., Jensen, J. P., Branco, C. W. C. (2007). Restoration of shallow lakes by nutrient control and biomanipulation - the successful strategy varies with lake size and climate. Hydrobiologia, 581(1), 269-285.

Jeppesen, E., Søndergaard, M., Mazzeo, N., Meerhoff, M., Branco, C. C., Huszar, V., \& Scasso, F. (2005). Lake restoration and biomanipulation in temperate lakes: relevance for subtropical and tropical lakes. Restoration and management of tropical eutrophic lakes, 341-359.

Kallis, G., \& Butler, D. (2001). The EU water framework directive: measures and implications. Water policy, 3(2), 125-142.

Lineman, M. J., Do, Y., Kim, J. Y., \& Joo, G. J. (2014). Mistakes Made, Lessons Learned: The Eulsukdo Wetland Restoration Program. 한국환경과학회지, 23(8), 1523-1536.

Liu, J., \& Diamond, J. (2005). China's environment in a globalizing world. Nature, 435(7046), 1179.

Loomis, J. (2006). Importance of including use and passive use values of river and lake restoration. Journal of Contemporary Water Research \& Education, 134(1), 4-8.

Magilligan, F. J., Graber, B. E., Nislow, K. H., Chipman, J. W., Sneddon, C. S., \& Fox, C. A. (2016). River restoration by dam removal: Enhancing connectivity at watershed scales. Elem Sci Anth, 4.

Mazur, R., Kałuża, T., Chmist, J., Walczak, N., Laks, I., \& Strzeliński, P. (2016). Influence of deposition of fine plant debris in river floodplain shrubs on flood flow conditions-The Warta River case study. Physics and Chemistry of the Earth, Parts A/B/C, 94, 106-113. 
Moss, B. (2008). The Water Framework Directive: total environment or political compromise?. Science of the total environment, 400(1-3), 32-41.

Mostert, E. (2003). The European water framework directive and water management research. Physics and Chemistry of the Earth, Parts A/B/C, 28(12-13), 523-527.

Naiman, R. J. 1988. Animal influence on ecosystem dynamics. BioScience 38(11).

National Research Council. (1992). Restoration of aquatic ecosystems: science, technology, and public policy. National Academies Press.

O'Connor JE, Duda JJ, Grant GE. 2015. 1000 dams down and counting. Science 348: 496-497. DOI: 10.1126/ science.aaa9204.

Olem, H., \& Flock, G. (1990). Lake and reservoir restoration guidance manual (No. PB-93-207926/XAB; EPA-440/4-90/006). North American Lake Management Society, Merrifield, VA (United States).

Ongley, E. D., Xiaolan, Z., Tao, Y. (2010). Current status of agricultural and rural non-point source pollution assessment in China. Environmental Pollution, 158(5), 11591168.

Palmer, M., Allan, J. D., Meyer, J., \& Bernhardt, E. S. (2007). River restoration in the twenty-first century: data and experiential knowledge to inform future efforts. Restoration Ecology, 15(3), 472-481.

Paturej, E. Wpływ Rekultywacji na Trofię Jeziora Śródmiejskiego. 2008. Acta Sci. Pol., Formatio Circumiectus. 7 (1), 3-12.

Reitzel, K., Hansen, J., Andersen, F. Ø., Hansen, K. S., Jensen, H. S. (2005). Lake restoration by dosing aluminum relative to mobile phosphorus in the sediment. Environ. science \& technology, 39(11), 4134-4140.

Schauser, I., Chorus, I. (2007). Assessment of internal and external lake restoration measures for two Berlin lakes. Lake and Reservoir Management, 23(4), 366-376.

Seavy, N. E., Howell, C. A. (2010). How can we improve information delivery to support conservation and restoration decisions?. Biodiversity and Conservation, 19(5), 1261-1267.

Skov, C., Hansen, J. H., Baktoft, H., Brodersen, J., Brönmark, C., Hansson, L. A., Nilsson, P. A. (2019). Biomanipulating streams: a supplementary tool in lake restoration. Hydrobiologia, 829(1), 205-216.

Smol, J. P. (2009). Pollution of lakes and rivers: a paleoenvironmental perspective. John Wiley \& Sons.

Spencer, J. (1985). A Plague of Beavers. Am. For. 91(5):22$27,62-63$.
Traczykowski, A., Berleć, K., \& Rzepczyk, B. (2009). Jakość wód powierzchniowych po rekultywacji na przykładzie Jeziora Głęboczek. Rocznik Ochrona Środowiska. Annual Set The Environment Protection, Middle Pomeranian Scientific Society of the Environment Protection, Koszalin, 11, 507-515.

U.S. Army Corps of Engineers and U.S. Environmental Protection Agency. (1990). Memorandum

Ustawa z dnia 9 października 2015 r. o rewitalizacji, Dz.U. 2015 poz. 1777

Ustawa z dnia z dnia 13 kwietnia 2018 r - Prawo Ochrony Środowiska, Dz.U. 2018 poz. 799

Ustawa z dnia 20 lipca 2017 r. - Prawo wodne, Dz.U. 2017 poz. 1566

Wiśniewski, R. (2007). The condition and potential methods of restoration of shallow, urban Lake Jelonek. Environment Protection Engineering, 33(2), 231-240.

Wright, D. I. (1984). Lake restoration by biomanipulation: Round Lake, Minnesota, the first two years. Freshwater biology, 14(4), 371-383.

Zhao, S., Fang, J., Ji, W., Tang, Z. (2003). Lake restoration from impoldering: impact of land conversion on riparian landscape in Honghu Lake area, Central Yangtze. Agriculture, ecosystems \& environment, 95(1), 111-118.

Młyński, D., Chmielowski, K., Młyńska, A. (2017). Analiza zmienności ilościowej ścieków dopływających do wybranych oczyszczalni powiatu sanockiego. Acta Sci. Pol. Formatio Circumiectus, 16(1), 77-90.

Bugajski, P., Chmielowski, K., Kaczor, G. (2016a). Optimizing the Percentage of Sewage from Septic Tanks for Stable Operation of a Wastewater Treatment Plant. Polish Journal of Environmental Studies, 25(4).

Bugajski, P., Chmielowski, K., Kaczor, G. (2016b). Wpływ wielkości dopływu wód opadowych na skład ścieków surowych w małym systemie kanalizacyjnym. Acta Scientiarum Polonorum Formatio Circumiectus, 15(2), $3-11$.

Mazur, R., Bedla, D., Chmielowski, K., Nowak, A., Mazurkiewicz, J. (2016). Wpływ warunków tlenowych na skuteczność oczyszczania ścieków bytowych w technologii zatapialnych filtrów włókninowych. Przemysł Chemiczny, 95(8), 1513-1517.

Chmielowski, K., Ślizowski, R. (2008). Defining the optimal range of a filter bed's d10 replacement diameter in vertical flow sand filters. Environment Protection Engineering, 34(3), 35-42. 


\section{REKULTYWACJA JEZIOR: ANALIZA BŁĘDNIE ZASTOSOWANEJ TERMINOLOGII W LITERATURZE FACHOWEJ}

\section{ABSTRAKT}

\section{Cel badań}

Główny celem badań była analiza błędnie zastosowanego sformułowania „rekultywacja wód” oraz „rekultywacja zbiorników wodnych”, w odniesieniu do błędów, których należy unikać w opisywaniu procesów związanych z odnową wód powierzchniowych.

\section{Materiat i metody}

Jest to praca przeglądowa bazująca na pracach naukowych oraz raportach branżowych w tematyce rekultywacji oraz odnowy wód powierzchniowych i zdegradowanych zbiornikach wodnych. Autor przeprowadził analizę błędnie zastosowanych sformułowań oraz zaproponował poprawną formę nazewnictwa w odniesieniu do opisywanych działań naprawczych.

\section{Wyniki i wnioski}

Wyniki analiz wskazują dobitnie, że autorzy wielokrotnie błędnie urzywają sformułowania rekultywacja wód w swoich artykułach. W literaturze naukowej oraz branżowej sformułowanie „rekultywacja wód” jest nadużywane pomimo rekomendacji światowej klasy ekspertów z Committee on Restoration of Aquatic Ecosystems in USA, którzy przedstawili w swoich raportach definicję sformułowania rekutywacja wód.

Słowa kluczowe: rekultywacja wód, rekultywacja zbiorników wodnych, odnowa wód powierzchniowych, zanieczyszczenia wodne 